\title{
PERSEPSI SISWA TENTANG PEMANFAATAN FASILITAS \\ DAN MOTIVASI BELAJAR TERHADAP PRESTASI BELAJAR
}

\author{
Mega Anastasia Widyati \\ Bety Nur Achadiyah \\ Universitas Negeri Malang, Fakultas Ekonomi \\ Mega_0603@yahoo.com
}

\begin{abstract}
The objective of this study is to evaluate the effects of school facilities and motivation to the learning achievement of accounting students at SMK Ardjuna 2 Malang. The participants of this study are 36 students from XI and XII class. The results of the study suggest that: (1) there is a positive effect between students' perception on school facilities toward learning achievement in accounting, and (2) there is a positive effect of students' motivation toward learning achievement in accounting. There are several things to do for the improvement: (1) The school should improve the school facilities, (2) Teacher should guide and motivate the students to increase the school facilities usage and motivate the students to increase the learning motivation and (3) the next research should find another factor to examine the learning achievement.
\end{abstract}

Keywords: Perception on school facilities, learning motivation, learning achievement.

\begin{abstract}
Abstrak: Penelitian ini bertujuan untuk mengetahui pengaruh pemanfaatan fasilitas belajar di sekolah dan motivasi belajar terhadap prestasi belajar siswa akuntansi SMK Ardjuna 2 Malang. Penelitian ini dilaksanakan terhadap siswa kelas XI dan XII Akuntansi SMK Arjuna 2 Malang dengan 36 responden. Hasil penelitian menunjukkan (1) terdapat pengaruh positif antara persepsi siswa tentang pemanfaatan fasilitas belajar di sekolah terhadap prestasi belajar siswa akuntansi; dan (2) Terdapat pengaruh positif antara persepsi siswa tentang motivasi belajar terhadap prestasi belajar siswa akuntansi. Saran dalam penelitian ini adalah: (1) Pihak sekolah hendaknya meningkatkan fasilitas belajar di sekolah; (2) guru hendaknya memberikan bimbingan dan motivasi kepada anak didiknya agar lebih memanfaatkan fasilitas belajar yang tersedia di sekolah; dan (3) bagi penelitian selanjutnya hendaknya mengkaji faktor-faktor lain yang berpengaruh dengan prestasi belajar yang belum diungkap dan dibahas dalam penelitian ini.
\end{abstract}

Kata kunci: Persepsi Siswa tentang Fasilitas Belajar di Sekolah, Motivasi Belajar, Prestasi Belajar.

Pendidikan merupakan salah satu faktor yang sangat menentukan kemajuan suatu bangsa. Dengan bekal pendidikan yang memadai, kualitas sumber daya manusia Indonesia akan mampu berkembang. Sukmadinata (2004: 172) menyatakan bahwa individu akan selalu berkembang dan sebagian besar perkembangan tersebut diperoleh dari belajar.

Sekolah merupakan suatu tempat dimana individu (siswa) melaksanakan kegiatan belajarnya secara formal. Dalam UU Sisdiknas No. 20 Tahun 2003 pasal 45 ayat 1 disebutkan bahwa setiap satuan pendidikan formal dan nonformal menyediakan sarana dan prasarana 
yang memenuhi keperluan pendidikan sesuai dengan sosial, emosional dan kejiwaan peserta didik. Sukmadinata (2004: 164) menyebutkan bahwa lingkungan belajar atau sekolah juga memiliki peranan penting bagi perkembangan belajar para siswanya. Lingkungan ini meliputi lingkungan fisik sekolah di antaranya lingkungan sekolah, sarana dan prasarana belajar yang ada, sumber-sumber belajar dan media belajar, dan sebagainya. Sekolah haruslah menyediakan sarana dan prasarana yang memadai dalam mendukung belajar para siswanya. Keberadaan fasilitas sekolah memiliki arti yang sangat penting, karena dapat meningkatkan aktivitas dan kreativitas belajar. Oleh karena itu, keberadaan fasilitas sekolah harus dimanfaatkan oleh siswa secara optimal

Tersedianya fasilitas sekolah yang lengkap dan memadai bukanlah satu-satunya jaminan bahwa prestasi belajar siswa akan meningkat. Faktor lain yang juga berperan dalam pencapaian prestasi belajar yang baik adalah motivasi belajar dari diri masing-masing individu. Menurut Sukmadinata (2004: 61) motivasi merupakan kekuatan yang menjadi pendorong kegiatan individu, yang menunjukkan suatu kondisi dalam diri individu yang mendorong atau menggerakkan individu tersebut. Menurut Dimyati (2002: 90) jenis motivasi ada dua yaitu: motivasi intrinsik dan ekstrinsik. Motivasi instrinsik yaitu motivasi yang berasal dari diri siswa sendiri yang mendorong siswa untuk mencapai prestasi tinggi dan melakukan kegiatan mencapai tujuan. Dalam arti apabila motivasi berprestasi siswa tinggi maka akan membuat siswa terus bersemangat guna mencapai prestasi yang diinginkan. Siswa yang memiliki motivasi berprestasi yang tinggi cenderung bergairah dalam belajar, sedang siswa yang memiliki motivasi berprestasi rendah akan menunjukkan hasil prestasi yang biasa-biasa saja atau cenderung menurun prestasinya.

Prestasi belajar menurut Dimyati dan Mudjiono (1999:250) merupakan hal yang dapat dipandang dari dua sisi yaitu siswa dan dari guru. Dari sisi siswa, prestasi belajar merupakan tingkat perkembangan mental yang lebih baik bila dibandingkan pada saat belum belajar. Prestasi belajar merupakan kegiatan evaluasi baik berupa pemberian tugas maupun ulangan yang diberikan oleh guru. Siswa yang berhasil dalam kegiatan belajarnya akan menunjukkan hasil yang baik dan optimal, berbeda dengan siswa yang kurang berhasil dalam kegiatan belajarnya maka akan menunjukkan hasil belajar yang kurang memuaskan atau rendah. Dari sisi guru, guru berperan dalam memberikan nilai yang adil dan bijak kepada siswa dengan memperhatikan kemampuan siswanya.

Dari uraian di atas disebutkan beberapa faktor yang mempengaruhi prestasi belajar di antaranya fasilitas belajar dan motivasi belajar. Fasilitas belajar merupakan sarana dan prasarana yang dapat menunjang atau membantu siswa dalam belajar, sedangkan motivasi 
belajar adalah hal yang mendorong siswa untuk melakukan sesuatu. Fasilitas belajar yang cukup memadai tidak akan bermanfaat apabila siswa tidak memanfaatkannya secara optimal untuk menunjang kegiatan belajar mengajar. Dengan adanya fasilitas yang lengkap diharapkan siswa mempunyai persepsi yang positif terhadap fasilitas tersebut. Misalnya ketika siswa mulai jenuh belajar di kelas dengan metode ceramah yang disampaikan guru, guru dapat menggunakan laboratorium untuk kegiatan belajar mengajar, jadi siswa akan lebih termotivasi untuk mengikuti pelajaran dan berlomba untuk mendapatkan nilai yang baik.

Walgito (2002:69) menyatakan bahwa persepsi merupakan suatu proses yang didahului oleh proses penginderaan, yaitu merupakan proses diterimanya stimulus oleh individu melalui alat indera. Pengajaran guru di kelas merupakan stimulus yang diterima oleh siswa melalui inderanya. Stimulus yang diterima melalui indera siswa diteruskan oleh syaraf sensoris ke otak. Proses yang terjadi dalam otak inilah yang disebut sebagai persepsi. Persepsi siswa dalam penelitian ini yaitu tentang pemanfaatan fasilitas belajar di sekolah dan motivasi belajar yang kemudian diorganisasikan dan diinterpretasikan sehingga menimbulkan respon pada diri siswa yang tergantung bagaimana siswa menyikapi. Apakah siswa akan menyikapi stimulus tersebut sehingga menimbulkan interpretasi yang positif dalam memaknai dan memberikan pengaruh yang positif juga dalam aktivitas mental siswa yaitu motivasi, atau sebaliknya menyikapi sebagai hal yang negatif sehingga menimbulkan interpretasi yang negatif dalam memaknai stimulus tersebut. Dengan demikian, apabila persepsi siswa tentang pemanfaatan fasilitas belajar di sekolah dan motivasi siswa dalam proses pembelajaran positif maka siswa akan termotivasi untuk melakukan kegiatan belajar untuk meningkatkan prestasi belajarnya.

Penelitian ini menguji pengaruh persepsi tentang pemanfaatan fasilitas belajar dan motivasi belajar terhadap prestasi belajar. Penelitian ini akan dilakukan di SMK Ardjuna 2 Malang. SMK Ardjuna 2 Malang adalah salah satu sekolah kejuruan swasta di Malang yang memiliki jurusan atau program keahlian akuntansi dan fasilitas belajar yang dapat menunjang kelancaran kegiatan belajar mengajar. Fasilitas yang dimiliki antara lain: ruang kelas yang luas, perpustakaan, laboratorium komputer, media pengajaran yang digunakan guru berupa LCD proyektor dan tape recorder, koperasi siswa untuk praktek penjualan, dan bank mini. Adanya fasilitas tersebut diharapkan dapat dimanfaatkan oleh siswa dengan optimal. Berdasarkan pengamatan peneliti siswa kurang memanfaatkan fasilitas yang disediakan sekolah, dikarenakan lokasi perpustakaan yang jadi satu dengan SMP Ardjuna 2 sehingga anak-anak malas pergi ke perpustakaan. Selain itu motivasi belajar siswa berada 
pada tingkat yang kurang. Hal ini dibuktikan dengan kurangnya perhatian siswa pada saat mengikuti proses belajar mengajar.

Berdasarkan latar belakang tersebut, penelitian ini bertujuan menguji kembali pengaruh persepsi siswa tentang pemanfaatan fasilitas belajar di sekolah dan motivasi belajar terhadap prestasi belajar siswa dengan mengambil lokasi penelitian di SMK Ardjuna 2 Malang.

\section{METODE}

Penelitian ini menggunakan rancangan deskriptif korelasional. Penelitian korelasional bermaksud untuk mengungkapkan hubungan korelatif antar variabel, dan dengan demikian dalam rancangan penelitian korelational peneliti harus melibatkan paling tidak dua variabel (Sukmadinata, 2004:46). Penelitian ini menggunakan deskriptif korelasional sebab peneliti ingin mengetahui pengaruh antara variabel bebas (persepsi tentang pemanfaatan fasilitas belajar di sekolah dan motivasi belajar) dengan variabel terikat (prestasi belajar siswa jurusan akuntansi) serta mendeskripsikan pemanfaatan fasilitas belajar di sekolah, motivasi belajar siswa dan prestasi belajar siswa.

Hubungan antara variabel tersebut dapat digambarkan sebagai berikut.

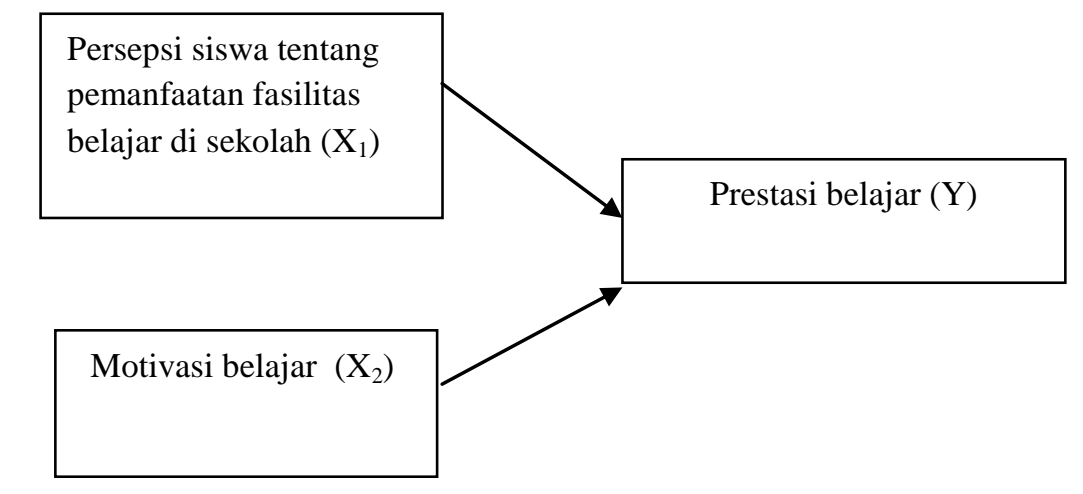

Gambar 1: Desain Penelitian

Populasi dari penelitian ini adalah siswa akuntansi SMK Ardjuna 2 Malang. Teknik pengambilan sampel dengan menggunakan purposive sampling. Sampel dari penelitian ini siswa kelas XI dan XII akuntansi SMK Ardjuna 2 Malang sebanyak 36 siswa, dalam penelitian ini tidak menggunakan siswa kelas $\mathrm{X}$ karena siswa kelas $\mathrm{X}$ belum mendapatkan raport yang digunakan untuk pengukuran variabel prestasi belajar. 
Tabel 1. Sampel Penelitian

\begin{tabular}{lll}
\hline No. & Kelas & Jumlah siswa \\
\hline 1. & XI Ak & 18 \\
$2 . \quad$ XII Ak & 18 \\
\hline Jumlah & $\mathbf{3 6}$ \\
\hline
\end{tabular}

(Sumber: TU SMK Ardjuna 2 Malang)

Instrumen yang digunakan untuk mengumpulkan data adalah kuesioner/angket. Instrumen dikembangkan oleh peneliti mengacu pada indikator sebagaimana terlihat pada tabel berikut.

Tabel 2. Jabaran Instrumen Penelitian

\begin{tabular}{|c|c|c|c|c|}
\hline Variabel & Sub Variabel & Indikator & $\begin{array}{l}\text { Nomor } \\
\text { Item }\end{array}$ & Jumlah \\
\hline \multirow{16}{*}{$\begin{array}{l}\text { Variabel Bebas } \\
\text { (X1): } \\
\text { Persepsi tentang } \\
\text { Pemanfaatan } \\
\text { fasilitas belajar di } \\
\text { sekolah }\end{array}$} & 1. Ruang kelas & 1. Kondisi kelas & 1 & 1 \\
\hline & & 2. Luas ruang kelas & 2 & 1 \\
\hline & & 3. Kelengkapan kelas & 3 & 1 \\
\hline & & 4. Pengaturan kelas & 4 & 1 \\
\hline & 2. Perpustakaan & 1. Kondisi buku & 5,6 & 2 \\
\hline & & 3. Jenis bahan pustaka & 7 & 1 \\
\hline & & 4. Peminjaman bahan pustaka & 8 & 1 \\
\hline & & & $9,10,11,12$ & 4 \\
\hline & & 5. Jenis bahan yang dibaca & 13 & 1 \\
\hline & & $\begin{array}{l}\text { 6. Waktu yang digunakan di } \\
\text { perpustakaan }\end{array}$ & 14 & 1 \\
\hline & 3. Laboratorium & 1. Pemanfaatan waktu & 15,16 & 2 \\
\hline & & 2. Pemanfaatan alat-alat & 17 & 1 \\
\hline & & 3. Kondisi alat-alat & 18 & 1 \\
\hline & $\begin{array}{l}\text { 4. } \begin{array}{l}\text { Media } \\
\text { pembelajaran }\end{array}\end{array}$ & $\begin{array}{l}\text { 1. Pemanfaatan media dan alat } \\
\text { pengajaran oleh guru }\end{array}$ & 19,20 & 2 \\
\hline & & $\begin{array}{l}\text { 2. Macam-macam } \\
\text { pembelajaran } \\
\text { digunakan oleh guru }\end{array}$ & 21 & 1 \\
\hline & & 3. Manfaat media bagi siswa & 22,23 & 2 \\
\hline
\end{tabular}




\begin{tabular}{|c|c|c|c|c|c|}
\hline \multirow{2}{*}{$\begin{array}{l}\text { Variabel } \\
(\mathrm{X} 2): \\
\text { Persepsi } \\
\text { motivasi } \\
\text { siswa }\end{array}$} & $\begin{array}{l}\text { Bebas } \\
\text { tentang } \\
\text { belajar }\end{array}$ & $\begin{array}{ll}\text { 1. } & \text { Motivasi } \\
\text { Intrinsik }\end{array}$ & $\begin{array}{l}\text { 1. Rasa ingin tahu } \\
\text { 2. Kemauan untuk belajar } \\
\text { 3. Ketekunan dalam belajar } \\
\text { 4. Minat/ketertarikan }\end{array}$ & $\begin{array}{l}1,2,3 \\
4,5,6,7,8 \\
9,10,11 \\
12,13,14\end{array}$ & $\begin{array}{l}3 \\
5 \\
3 \\
3\end{array}$ \\
\hline & & $\begin{array}{ll}\text { 2. } & \text { Motivasi } \\
\text { Ekstrinsik }\end{array}$ & $\begin{array}{l}\text { 1. Persaingan dengan teman } \\
\text { dalam hal belajar } \\
\text { 2. Ingin mendapatkan } \\
\text { penghargaan man belajar } \\
\text { 3. Pemanfaatan jam bas } \\
\text { 4. Fasilitas yang ada }\end{array}$ & $\begin{array}{l}15,16,17, \\
18 \\
19 \\
20,21,22 \\
23\end{array}$ & $\begin{array}{l}3 \\
1\end{array}$ \\
\hline $\begin{array}{l}\text { Variabel } \\
\text { (Y): } \\
\text { Prestasi } \\
\text { siswa }\end{array}$ & $\begin{array}{l}\text { Terikat } \\
\text { Belajar }\end{array}$ & Hasil belajar & Nilai raport & $\begin{array}{l}\text { Nilai } \\
\text { raport }\end{array}$ & \\
\hline
\end{tabular}

Setelah diklarifikasi dan di coding, data yang terkumpul dianalisis secara kuantitatif yaitu dideskripsikan sesuai dengan fakta yang diperoleh. Skala pengukuran data yang dipergunakan dalam penelitian ini adalah skala likert, skala yang berhubungan dengan pernyataan sikap seseorang terhadap sesuatu dengan interval penilaian untuk setiap jawaban responden 1-4, skala ini digunakan untuk mengukur persepsi pemanfaatan fasilitas belajar di sekolah dan motivasi belajar. Interval jawaban responden akan disesuaikan dengan pernyataan yang diajukan.

Analisis data dalam penelitian ini menggunakan statistik deskriptif dan statistik inferensial. Statistik deskriptif adalah statistik yang digunakan untuk menganalisis data dengan cara mendeskriptifkan atau menggambarkan data yang telah terkumpul sebagaimana adanya tanpa bermaksud membuat kesimpulan yang berlaku untuk umum atau generalisasi (Sugiyono, 2008: 206). Analisis statistik inferensial yang digunakan dalam penelitian ini adalah analisis regresi linier berganda. Teknik perhitungan analisis regresi berganda menggunakan program SPSS for windows. Pengujian hipotesis dalam penelitian ini adalah uji $\mathrm{t}$ yaitu dengan cara membandingkan hasil sig. t dengan alpha $(\alpha)$. Jika signifikansi $\mathrm{t}$ $\leq 0,05$, maka hipotesis nol $\left(\mathrm{H}_{\mathrm{o}}\right)$ tidak didukung dan hipotesis alternatif $\left(\mathrm{H}_{\mathrm{a}}\right)$ diterima, sedangkan jika signifikansi $\mathrm{t}>0,05$, maka hipotesis nol $\left(\mathrm{H}_{\mathrm{o}}\right)$ diterima dan hipotesis alternatif $\left(\mathrm{H}_{\mathrm{a}}\right)$ tidak didukung. 


\section{HASIL DAN PEMBAHASAN}

\section{Pengaruh Persepsi Siswa tentang Fasilitas Belajar di Sekolah terhadap Prestasi Belajar}

Variabel persepsi siswa tentang fasilitas belajar di sekolah dalam penelitian ini diukur dengan menggunakan beberapa indikator yang telah dijelaskan sebelumnya. Indikator tersebut kemudian dikembangkan ke dalam 23 pertanyaan.

Berdasarkan deskripsi data dari penelitian dapat diketahui bahwa dari 36 responden yang diteliti, 1 responden dengan persentase 2,78\% menyatakan fasilitas belajar di sekolah sangat baik. Tiga puluh satu responden dengan persentase $86,11 \%$ menyatakan bahwa fasilitas belajar di sekolah adalah baik, 4 responden dengan persentase $11,11 \%$ menyatakan fasilitas belajar di sekolah kurang baik, serta 0 responden dengan persentase $0 \%$ menyatakan fasilitas belajar di sekolah tidak baik. Nilai tertinggi yang diperoleh fasilitas belajar di sekolah adalah 92 dan nilai terendah adalah 24. Nilai rata-rata fasilitas belajar di sekolah adalah 66,61 setara dengan kriteria baik dalam interval 62-80.

Tabel 3. Distribusi Frekuensi Persepsi Siswa tentang Fasilitas Belajar di Sekolah

\begin{tabular}{lllll}
\hline No & Interval & Kriteria & Frekuensi & Prosentase \\
\hline 1 & $81-99$ & Sangat Baik & 1 & $2,78 \%$ \\
2 & $62-80$ & Baik & 31 & $86,11 \%$ \\
3 & $43-61$ & Kurang Baik & 4 & $11,11 \%$ \\
4 & $24-42$ & Tidak Baik & 0 & $0 \%$ \\
\hline Jumlah & & $\mathbf{3 6}$ & $\mathbf{1 0 0 \%}$ \\
\hline
\end{tabular}

Sumber: (Data diolah)

Dari hasil analisis data, diketahui untuk variabel persepsi siswa tentang fasilitas belajar di sekolah di peroleh nilai B sebesar 0,027 t hitung $(2,311)>t$ tabel $(2,034)$ dengan probabilitas $(0,027) \leq 0.05$ pada taraf signifikansi $5 \%$, maka Ho ditolak dan $\mathrm{H}_{1}$ diterima. Dengan demikian, dapat disimpulkan bahwa "terdapat pengaruh positif yang signifikan tentang persepsi siswa tentang fasilitas belajar di sekolah terhadap prestasi belajar siswa akuntansi SMK Ardjuna 2 Malang”.

Berdasarkan hasil penelitian tersebut, maka hasil penelitian ini membuktikan pendapat Sutrisna (1997: 135-136) yang menyatakan bahwa "kelengkapan sarana dan prasarana seperti gedung sekolah yang menyenangkan, fasilitas kelas yang bersih, teratur dan memberikan kenyamanan lingkungan akan mendorong siswa untuk berprestasi di dalam belajarnya".

Semakin baik fasilitas belajar yang dimiliki sekolah, maka prestasi belajar siswa juga akan semakin tinggi. Dalam penelitian ini, fasilitas belajar di SMK Ardjuna 2 berada dalam keadaan baik, sehingga prestasi belajar siswa akuntansi tinggi. Oleh karena itu, apabila fasilitas belajar di sekolah dapat ditingkatkan menjadi lebih baik dan lebih memadai, maka 
prestasi belajar siswa pun pasti akan meningkat lagi/ semakin tinggi. Misalnya dengan penambahan buku-buku yang ada di perpustakaan untuk menunjang proses pembelajaran, perbaikan laboratorium komputer supaya siswa lebih nyaman ketika melakukan praktikum akuntansi. Fasilitas belajar yang memadai dapat memudahkan siswa dalam menerima pelajaran dan kegiatan belajar mengajar dapat berjalan dengan teratur, efisien, dan efektif sehingga mereka dapat meningkatkan prestasi belajarnya.

\section{Pengaruh Persepsi Siswa tentang Motivasi Belajar terhadap Prestasi Belajar Siswa}

\section{Akuntansi SMK Ardjuna 2 Malang}

Variabel persepsi siswa tentang motivasi belajar siswa dalam penelitian ini diukur dengan menggunakan beberapa indikator yang telah dijelaskan pada bab sebelumnya. Indikator tersebut kemudian dikembangkan ke dalam 23 pertanyaan.

Berdasarkan deskripsi dari hasil penelitian dapat diketahui bahwa dari 36 responden yang diteliti, 3 responden dengan persentase 8,33\% menyatakan bahwa motivasi belajar mereka sangat tinggi. 26 responden dengan persentase $72,22 \%$ menyatakan motivasi belajar mereka tinggi, 7 responden dengan persentase 19,44\% menyatakan motivasi belajar mereka cukup tinggi, serta 0 responden dengan persentase $0 \%$ menyatakan motivasi belajar mereka rendah.. Nilai tertinggi yang diperoleh fasilitas belajar di sekolah adalah 92 dan nilai terendah adalah 24. Nilai rata-rata motivasi belajar siswa adalah 66,42 setara dengan kriteria tinggi dalam interval 52-67. Ini berarti motivasi belajar mereka adalah tinggi.

Tabel 4. Distribusi Frekuensi Motivasi Belajar Siswa

\begin{tabular}{lllll}
\hline No & Interval & Kriteria & Frekuensi & Prosentase \\
\hline 1 & $68-83$ & Sangat Tinggi & 3 & 8,33 \\
2 & $52-67$ & Tinggi & 26 & 72,22 \\
3 & $36-51$ & Cukup Tinggi & 11 & 19,44 \\
4 & $20-35$ & Rendah & 0 & 0 \\
\hline Jumlah & & $\mathbf{3 6}$ & $\mathbf{1 0 0 \%}$ \\
\hline
\end{tabular}

Dari hasil analisis data, diketahui untuk variabel persepsi siswa tentang motivasi belajar diperoleh koefisien B sebesar 0,021, t hitung (2,594) > t tabel $(2,034)$ dengan probabilitas $0,014 \leq 0,05$ pada taraf signifikansi 5\% maka Ho ditolak dan $\mathrm{H}_{2}$ diterima. Dengan demikian dapat disimpulkan bahwa, " terdapat pengaruh yang positif motivasi belajar siswa terhadap prestasi belajar siswa akuntansi SMK Ardjuna 2 Malang”.

Adanya pengaruh tersebut menunjukkan bahwa semakin tinggi motivasi belajar siswa, maka akan semakin baik atau semakin tinggi prestasi belajar siswa. Hal ini dikarenakan motivasi merupakan pendorong siswa dalam belajar, sehingga siswa akan lebih baik dalam 
belajarnya yang akan berdampak pada hasil belajar yang baik. Motivasi intrinsik terdiri dari rasa ingin tahu, kemauan untuk belajar, ketekunan dalam belajar, dan minat/ ketertarikan. Dengan adanya rasa ingin tahu, kemauan untuk belajar, ketekunan dalam belajar, dan minat/ ketertarikan belajar, akan sangat membantu siswa mencapai prestasi yang lebih baik, sedangkan indikator yang merupakan motivasi ekstrinsik yaitu persaingan dengan teman dalam hal belajar, ingin mendapatkan penghargaan, pemanfaatan jam belajar, dan fasilitas belajar. Seorang siswa karena ada rasa atau keinginan untuk memperoleh penghargaan terhadap prestasinya, untuk memperoleh nilai yang tinggi, ataupun untuk mendapatkan prestasi yang lebih baik dari temannya, maka sebagai usaha untuk mencapai tujuan belajarnya, siswa tersebut akan lebih baik dan rajin dalam belajar, sehingga prestasinya akan lebih baik. Sesuai dengan pendapat Sardiman (2003:84), yang menyatakan bahwa dalam belajar sangat diperlukan adanya motivasi, hasil belajar akan optimal kalau ada motivasi. Semakin tepat motivasi yang diberikan, akan semakin berhasil pula pelajaran itu. Dengan demikian motivasi akan senantiasa menentukan intensitas usaha belajar bagi para siswa.

Adanya pengaruh dua variabel terhadap prestasi belajar menunjukkan bahwa variabel bebas yaitu persepsi siswa tentang pemanfaatan fasilitas belajar di sekolah dan motivasi belajar secara bersama mempengaruhi prestasi belajar siswa. Artinya, setiap ada perubahan pada pemanfaatan fasilitas belajar dan motivasi belajar, akan berdampak positif yang signifikan terhadap prestasi belajar siswa akuntansi SMK Ardjuna 2 Malang. Apabila fasilitas belajar baik, motivasi belajar tinggi, maka prestasi belajar siswa akan semakin baik. Sebaliknya, apabila fasilitas belajar kurang baik, motivasi belajar rendah, maka prestasi belajar siswa akan kurang baik pula. Slameto (2003:54), menyatakan bahwa banyak faktor yang mempengaruhi belajar. Fasilitas belajar digolongkan sebagai faktorn ekstern yang mempengaruhi belajar. Motivasi belajar merupakan faktor psikologis yang digolongkan sebagai faktor intern yang mempengaruhi belajar.

\section{SIMPULAN}

Berdasarkan pembahasan hasil penelitian, maka kesimpulan yang dapat diambil dari penelitian ini adalah sebagai berikut; (1). terdapat pengaruh positif yang signifikan antara persepsi siswa tentang pemanfaatan fasilitas belajar di sekolah terhadap prestasi belajar siswa SMK Ardjuna 2 Malang. Dari hasil penelitian menunjukkan fasilitas yang di miliki sekolah dalam keadaan baik. Hal ini dapat diartikan bahwa semakin baik fasilitas yang dimiliki oleh sekolah tersebut maka akan semakin tinggi prestasi siswa untuk belajar. Hasil penelitian ini menunjukkan fasilitas belajar di SMK Ardjuna 2 Malang berada dalam keadaan baik, prestasi 
belajar siswa juga tinggi. Sehingga apabila fasilitas belajar di sekolah dapat ditingkatkan menjadi lebih baik dan lebih lengkap, maka prestasi belajar siswa pun pasti akan bertambah tinggi lagi; (2). Terdapat pengaruh positif yang signifikan antara persepsi siswa tentang motivasi belajar terhadap prestasi belajar siswa akuntansi SMK Ardjuna 2 Malang.

Berdasarkan kesimpulan penelitian di atas, maka saran yang dapat diberikan adalah sebagai berikut. (1). Untuk menunjang kegiatan belajar siswa, pihak sekolah diharapkan juga menyediakan fasilitas-fasilitas pendukung agar kegiatan belajar mengajar berjalan sesuai dengan perkembangan saat ini. (2). Diharapkan guru selalu memberikan bimbingan dan motivasi belajar untuk rajin belajar dan memanfaatkan fasilitas belajar yang tersedia di sekolah agar tercapai tujuan pembelajaran yaitu meningkatkan prestasi siswa. (3). Berdasarkan hasil penelitian, siswa akuntansi SMK Ardjuna 2 Malang memiliki prestasi belajar yang cukup dan diharapkan siswa dapat meningkatkan prestasi belajar tersebut dengan cara memaksimalkan pemanfaatan fasilitas belajar yang ada di sekolah seperti perpustakaan sekolah, laboratorium komputer, dan sebagainya untuk mencapai prestasi yang lebih baik.

\section{DAFTAR RUJUKAN}

Dimyati dan Mujiono. 1999. Belajar dan Pembelajaran. Jakarta: Dirjen Pendidikan Tinggi Depdikbud

Dimyati, dkk. 2002. Belajar dan Pembelajaran. Jakarta: Dirjen Pendidikan Tinggi Depdikbud

Slameto. 2003. Belajar dan Faktor-faktor yang Mempengaruhinya. Jakarta: Rineka Cipta

Sardiman. 2003. Interaksi dan Motivasi Belajar Mengajar. Jakarta: PT Raja Grafindo Persada

Sugiyono. 2008. Statistika untuk Penelitian. Bandung: CV Alfabeta

Sukmadinata, Nana. 2004. Landasan Psikologi Proses Pendidikan. Bandung: Remaja Rosdakarya

Sutrisna. 1997. Administrasi Pendidikan. Bandung: Angkasa

Walgito, B. 2002. Pengantar Psikologi Umum. Yogyakarta: Andi 